\title{
Preliminary assessment of the possibility of mercury removal from hard coal with the use of air concentrating tables
}

\section{Introduction}

Mercury and its compounds, which are characterized by highly toxic properties, negatively affect the nervous, respiratory and circulatory systems as well as the liver, kidneys, skin and fetus (UNEP 2013). Even a small amount of mercury emitted to the environment is a potential threat to human health, because the natural biogeochemical cycle of mercury occurs (Gworek and Rateńska 2009). One of the main sources of anthropogenic mercury emissions (24\% of total anthropogenic mercury emission) is the process of coal combustion (Pirrone et al. 2010; Sloss 2015). For that reason, under the Minamata Convention (Adamska 2014) the mercury emissions regulations (limits) for coal-fired power plants are currently being developed. Moreover, the limits of mercury emissions from both hard and brown coalfired plants have been established by the EU in the BAT Conclusions (European Commission 2017). It should be also mentioned, that regulations concerning mercury emissions are applied in some countries such as the US and Holland (Burmistrz and Kogut 2014).

The issue of mercury emissions is particularly important for Poland. Forecasts concerning energy consumption in Poland show that coal (mainly hard coal) will be the main source for energy production in the coming decades (Ministerstwo Gospodarki 2015). Therefore,

* Ph.D., Eng., ** D.Sc. Eng., Associate Professor of AGH, AGH University of Science and Technology, Faculty of Energy and Fuels, Krakow; e-mail: tadeusz.dziok@agh.edu.pl 
actions enabling the reduction of mercury emissions from coal-fired power plants will have to be implemented. These could involve the application of post-combustion methods (Burmistrz et al. 2014; Krzyżyńska et al. 2011; Wdowin et al. 2015) or pre-combustion methods (Chmielniak et al. 2015; Dziok et al. 2014, 2015b). The former allow for mercury removal from flue gases, and the latter allow for mercury removal from coal before its combustion. The advantage of the pre-combustion method is the production of coal with a reduced mercury content. Such coals can be used in the heat and power generation sector, the industrial plants of lower power, the municipal sector as well as in the coke production sector (Burmistrz et al. 2017) and in gasification plants (Porada et al. 2017).

The effectiveness of mercury removal from coal is determined by the mode of its occurrence in coal. In the case of mercury occurrence in the adventitious inorganic constituents of coal, high effectiveness will be obtained in the coal cleaning processes (Diehl et al. 2014, Dziok et al. 2015b). In the case of mercury occurrence in the organic matter as well as in the inherent inorganic constituents of coal, the effectiveness of this method will be low. For such coals mercury could be removed in the process of thermal pretreatment at the temperature of $200-400^{\circ} \mathrm{C}$ (mild pyrolysis). The thermal pretreatment process also enables mercury removal from inorganic constituents characterized by a relatively low temperature of mercury release (Strezov et al. 2010; Uruski et al. 2015).

In the paper, the possibility of mercury removal from hard coal in the process of dry deshaling on an air concentrating table was determined. This method allows for the gangues removal from raw coal (Baic et al. 2015a). In comparison to the coal washing processes, the dry deshaling process is characterized by both lower investment costs and lower operating costs. Additionally, the dry deshaling process allows for effective pyritic sulfur removal from raw coal, and generated rejects could be used as a substitute for the natural aggregates (Baic et al. 2015a, 2015b).

\section{Aim and scope of study}

The aim of the study was the preliminary assessment of the usefulness of air concentrating tables for mercury content reduction in hard coal. For this purpose raw coals (coal feed), clean coals and the rejects derived from dry deshaling of six Polish hard coals were analyzed. The mercury content was measured in the examined samples. The contents of mercury in raw coals and clean coals were compared. Additionally, with the usage of appropriate factors, the effectiveness of mercury removal from coal with rejects was described. 


\section{Experimental}

\subsection{Methods of research and analysis}

The mercury contents in the analyzed samples were determined with the use of the MA2000 Analyzer (Nippon Instruments Corporation), based on cold vapor atomic absorption spectroscopy (CVAAS), according to the EPA Method 7473. The proximate and ultimate analyses of the samples were performed according to ISO standards. The contents of moisture, ash and volatile matter were determined with the use of the TGA Thermostep Eltra Analyzer. The contents of carbon, hydrogen and sulfur were determined with the use of the CHS-580 Eltra Analyzer. The calorific value was determined with the use of the AC 350 Leco Calorimeter.

\subsection{Examined samples}

In the paper, six Polish hard coals as well as clean coals and the rejects derived from their dry deshaling were examined. The dry deshaling process was performed with the use of an air concentrating table of the FGX type, owned by the Institute of Mechanised Construction and Rock Mining (IMBiGS). The principles of the operation and construction of the air concentrating table, among others, were presented in works (Baic et al. 2015a, 2015c). The working outline of the applied air concentrating table is presented in Figure 1.

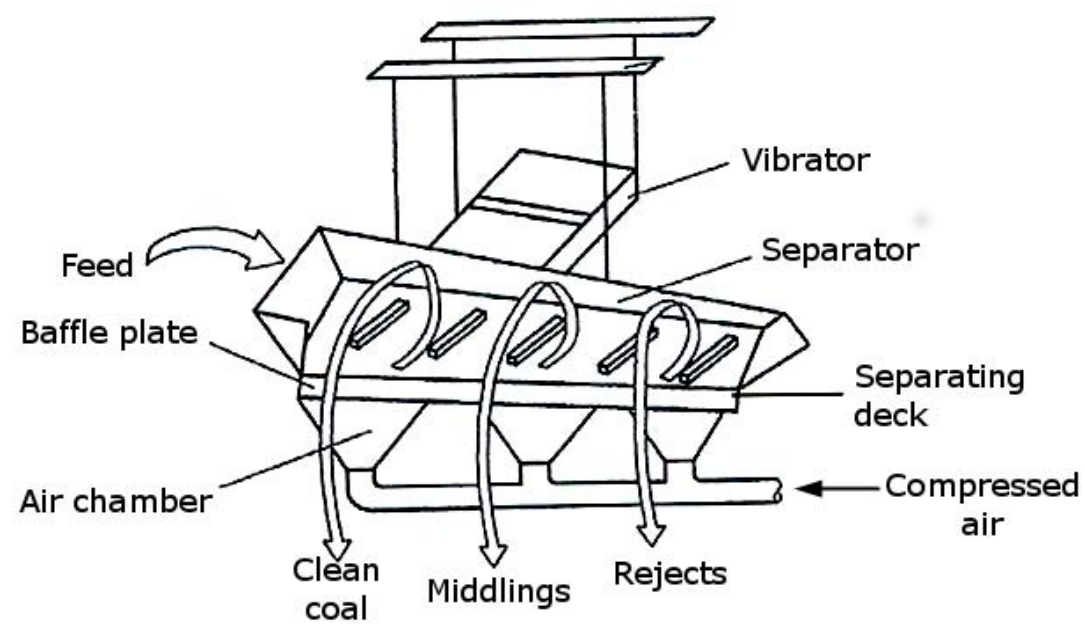

Fig. 1. Working outline of air concentrating table type FGX (Baic and Blaschke 2013)

Rys. 1. Zasada działania powietrznego stołu koncentracyjnego (Baic i Blaschke 2013) 
Compressed air is injected under the separating deck through the air chamber. The flow of air causes coal fluidization and separation on the basis of different density (a lower density clean coal, a higher density - the rejects). Additionally, in order to ensure a good separation of coal, the separating desk is put into reciprocating motion.

The capacity of the applied air concentrating table ranges from 3 to $7 \mathrm{Mg} / \mathrm{h}$. The mass of coal feed was at least $25 \mathrm{Mg}$. The coal feed was sampled directly in front of the separating desk. The products of coal separation (clean coal, rejects as well as middlings and coal dust)

Table. 1. Characteristics of raw coals (coal feed) used in the process of dry deshaling on an air concentrating table

Tabela 1. Charakterystyka węgli surowych (nadaw) poddanych procesowi suchego odkamieniania przy wykorzystaniu powietrznego stołu koncentracyjnego

\begin{tabular}{|c|c|c|c|c|c|c|c|c|c|c|}
\hline $\begin{array}{c}\text { Coal } \\
\text { number }\end{array}$ & $\begin{array}{c}\mathrm{M}^{\text {ar }} \\
{[\%]}\end{array}$ & $\begin{array}{c}\mathrm{M}^{\mathrm{ad}} \\
{[\%]}\end{array}$ & $\begin{array}{c}\mathrm{A}^{\mathrm{ar}} \\
{[\%]}\end{array}$ & $\begin{array}{c}\mathrm{V}^{\mathrm{daf}} \\
{[\%]}\end{array}$ & $\begin{array}{c}\mathrm{HHV}^{\mathrm{ad}} \\
{[\mathrm{MJ} / \mathrm{kg}]}\end{array}$ & $\begin{array}{c}\mathrm{LHV}^{\mathrm{ad}} \\
{[\mathrm{MJ} / \mathrm{kg}]}\end{array}$ & $\begin{array}{c}\mathrm{C}^{\mathrm{daf}} \\
{[\%]}\end{array}$ & $\begin{array}{c}\mathrm{H}^{\mathrm{daf}} \\
{[\%]}\end{array}$ & $\begin{array}{c}\mathrm{S}_{\mathrm{t}}^{\mathrm{d}} \\
{[\%]}\end{array}$ & $\begin{array}{c}\mathrm{Hg}_{\mathrm{t}}{ }^{\mathrm{d}} \\
{[\mu \mathrm{kg}]}\end{array}$ \\
\hline W1 & 9.5 & 4.6 & 25.0 & 35.8 & 22.0 & 21.1 & 78.4 & 4.96 & 1.45 & 108 \\
\hline W2 & 15.5 & 9.7 & 8.4 & 36.8 & 25.9 & 24.8 & 78.1 & 5.05 & 1.55 & 79 \\
\hline W3 & 5.9 & 2.6 & 43.1 & 37.2 & 17.1 & 16.4 & 78.3 & 5.21 & 0.56 & 133 \\
\hline W4 & 3.6 & 2.0 & 50.5 & 40.3 & 11.9 & 11.2 & 76.2 & 5.49 & 0.44 & 64 \\
\hline W5 & 3.0 & 1.6 & 64.5 & 46.2 & 7.2 & 6.7 & 73.2 & 5.60 & 0.41 & 122 \\
\hline W6 & 5.0 & 2.6 & 39.7 & 38.1 & 17.5 & 16.8 & 77.6 & 5.44 & 0.75 & 142 \\
\hline
\end{tabular}

ar - as received, ad - air dried, $d-$ dry, daf - dry and ash free.

Table. 2. Characteristics of clean coals derived from the process of dry coal deshaling on an air concentrating table

Tabela 2. Charakterystyka koncentratów z procesu suchego odkamieniania węgli kamiennych przy wykorzystaniu powietrznego stołu koncentracyjnego

\begin{tabular}{|c|c|c|c|c|c|c|c|c|c|c|c|}
\hline $\begin{array}{c}\text { Coal } \\
\text { number }\end{array}$ & $\begin{array}{c}\text { Yield } \\
{[\%]}\end{array}$ & $\begin{array}{c}\mathrm{M}^{\mathrm{ar}} \\
{[\%]}\end{array}$ & $\begin{array}{c}\mathrm{M}^{\text {ad }} \\
{[\%]}\end{array}$ & $\begin{array}{c}\mathrm{A}^{\mathrm{ar}} \\
{[\%]}\end{array}$ & $\begin{array}{c}\mathrm{V}^{\text {daf }} \\
{[\%]}\end{array}$ & $\begin{array}{c}\mathrm{HHV} \\
{[\mathrm{MJ} / \mathrm{kg}]}\end{array}$ & $\begin{array}{c}\mathrm{LHV} \\
{[\mathrm{MJ} / \mathrm{kg}]}\end{array}$ & $\begin{array}{c}\mathrm{C}^{\mathrm{daf}} \\
{[\%]}\end{array}$ & $\begin{array}{c}\mathrm{H}^{\mathrm{daf}} \\
{[\%]}\end{array}$ & $\begin{array}{c}\mathrm{S}_{\mathrm{t}}{ }^{\mathrm{d}} \\
{[\%]}\end{array}$ & $\begin{array}{c}\mathrm{Hg}_{\mathrm{t}}{ }^{\mathrm{d}} \\
{[\mu \mathrm{g} / \mathrm{kg}]}\end{array}$ \\
\hline $\mathrm{W} 1$ & 60.0 & 6.5 & 5.3 & 13.4 & 34.7 & 26.4 & 25.4 & 80.3 & 5.02 & 1.03 & 77 \\
\hline W2 & 74.3 & 15.9 & 9.6 & 6.1 & 36.9 & 26.6 & 25.5 & 78.3 & 5.03 & 1.26 & 37 \\
\hline W3 & 28.6 & 6.2 & 3.0 & 32.8 & 35.8 & 20.8 & 20.0 & 79.4 & 5.16 & 0.70 & 103 \\
\hline W4 & 33.3 & 5.2 & 3.4 & 8.1 & 36.1 & 29.2 & 28.0 & 82.1 & 5.33 & 0.91 & 56 \\
\hline W5 & 25.9 & 5.4 & 3.4 & 7.1 & 35.8 & 31.0 & 29.8 & 82.0 & 5.52 & 0.85 & 82 \\
\hline W6 & 26.6 & 6.3 & 2.8 & 34.5 & 37.5 & 19.9 & 19.1 & 77.8 & 5.33 & 0.87 & 169 \\
\hline
\end{tabular}

ar - as received, ad - air dried, d-dry, daf - dry and ash free. 
were sampled for further analyses from the whole cross-section of the obtained samples. The sampling as well as the preparation of laboratory samples were conducted according to the PN-90/G-04502 standard (Baic et al. 2015b).

The characteristics of raw coals (coal feed) used in the process of dry deshaling as well as the obtained clean coals and the rejects were presented in Tables 1,2 and 3, respectively. The tables also show the yields of obtained clean coals and rejects. The remaining part were the middlings and also for some cases a coal dust which was separated from the air used in the process of dry deshaling.

Table. 3 . Characteristics of rejects derived from the process of dry coal deshaling on an air concentrating table

Tabela 3. Charakterystyka odpadów z procesu suchego odkamieniania węgli kamiennych przy wykorzystaniu powietrznego stołu koncentracyjnego

\begin{tabular}{|c|c|c|c|c|c|c|c|c|}
\hline $\begin{array}{c}\text { Coal } \\
\text { number }\end{array}$ & $\begin{array}{c}\text { Yield } \\
{[\%]}\end{array}$ & $\begin{array}{c}\mathrm{M}^{\mathrm{ar}} \\
{[\%]}\end{array}$ & $\begin{array}{c}\mathrm{M}^{\mathrm{ad}} \\
{[\%]}\end{array}$ & $\begin{array}{c}\mathrm{A}^{\mathrm{ar}} \\
{[\%]}\end{array}$ & $\begin{array}{c}\mathrm{HHV} \\
{[\mathrm{MJ} / \mathrm{kg}]}\end{array}$ & $\begin{array}{c}\mathrm{LHV}^{\mathrm{ad}} \\
{[\mathrm{MJ} / \mathrm{kg}]}\end{array}$ & $\begin{array}{c}\mathrm{S}_{\mathrm{t}}^{\mathrm{d}} \\
{[\%]}\end{array}$ & $\begin{array}{c}\mathrm{Hg}_{\mathrm{t}}^{\mathrm{d}} \\
{[\mu \mathrm{g} / \mathrm{kg}]}\end{array}$ \\
\hline $\mathrm{W} 1$ & 7.0 & 2.7 & 1.8 & 81.3 & 2.6 & 2.3 & 2.88 & 319 \\
\hline W2 & 5.1 & 14.1 & 8.3 & 14.8 & 23.8 & 22.8 & 3.21 & 162 \\
\hline W3 & 64.4 & 3.3 & 3.5 & 46.6 & 15.5 & 14.8 & 0.57 & 93 \\
\hline W4 & 59.1 & 3.0 & 0.9 & 87.0 & 0 & 0 & 0.26 & 78 \\
\hline W5 & 74.1 & 1.8 & 0.9 & 89.5 & 0 & 0 & 0.25 & 160 \\
\hline W6 & 29.7 & 3.8 & 2.3 & 51.3 & 13.1 & 12.5 & 0.64 & 121 \\
\hline
\end{tabular}

ar - as received, ad - air dried, $\mathrm{d}-$ dry.

\section{Results and discussion}

A comparison of mercury content in raw coal and clean coals was performed for the preliminary assessment of the possibility of mercury removal from hard coal with the use of air concentrating tables. In Figure 2 the comparison of mercury content in raw coals (coal feed) and clean coals is presented. For most cases (cases W1-W5), a decrease in mercury content, in the range from $11 \%$ (case W4) to $53 \%$ (case W2), was obtained. However, it should be pointed out that for one case (i.e. case W6), the mercury content in clean coal increased by $19 \%$. According to our previous studies (Dziok et al. 2015a), such a diversity of the obtained results may be explained, among others, by the diversity of mercury occurrence in coal.

For steam coals, the mercury content should be always related to the amount of energy contained in coal, i.e. for example to the lower heating value of coal - Equation (1). 


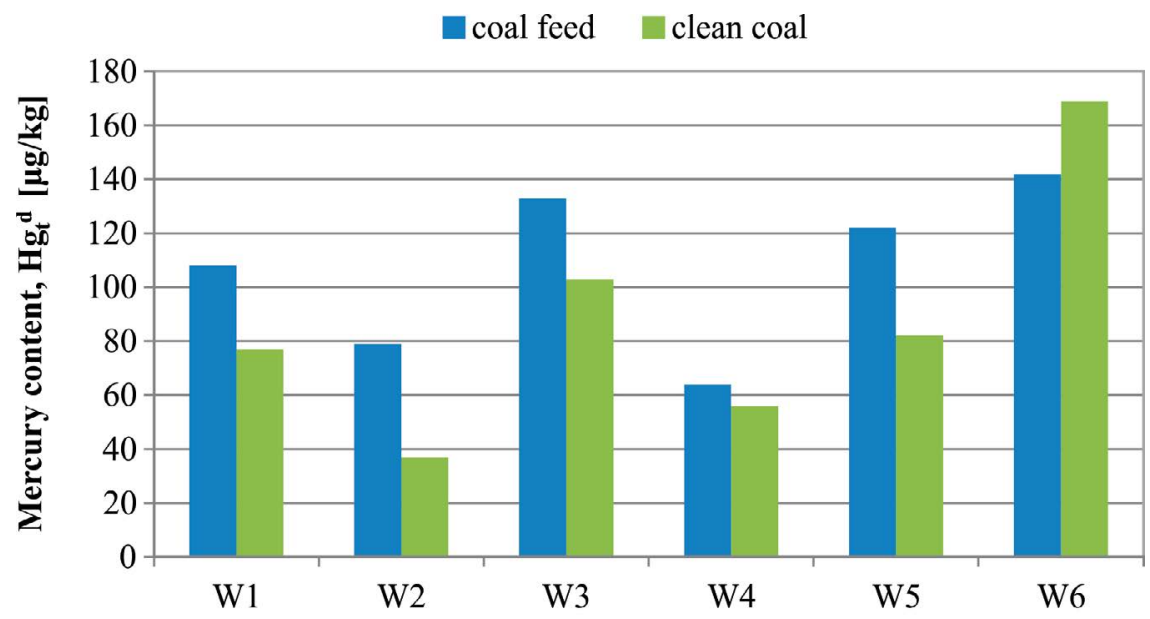

\section{Hard coal number used in dry deshaling process}

Fig. 2. Comparison of the mercury content in raw coals (coal feed) and clean coals derived from the process of dry coal deshaling on air concentrating table

Rys. 2. Porównanie zawartości rtęci w węglach surowych (nadawach) i koncentratach z procesu suchego odkamieniania przy wykorzystaniu powietrznego stołu koncentracyjnego

$$
H g_{c a l}=\frac{H g_{t}^{d}}{Q_{i}^{d}}
$$

(x) where:

$\mathrm{Hg}_{\text {cal }}$ - mercury content in relation to the lower heating value of coal $[\mu \mathrm{g} / \mathrm{MJ}]$,

$H g_{t}^{d}-$ mercury content in coal (dry basis) $[\mu \mathrm{g} / \mathrm{kg}]$,

$Q_{i}^{d} \quad-$ the lower heating value of coal (dry basis) $[\mathrm{MJ} / \mathrm{kg}]$.

The comparison of coal feed and clean coal for mercury content expressed in such a way is given in Figure 3. The effect of the dry deshaling process is clearer. For cases W1-W5, the dry deshaling process allowed for a mercury content decrease in coal in the range from $36 \%$ (case W3) to $83 \%$ (case W5). For case W6, the mercury content in clean coal was higher than in coal feed, as previously. However, the difference was not as significant (ca. 5\%).

At the next stage of the work, the values of the effectiveness factor of mercury removal from the analyzed coals in the dry deshaling process were estimated. This factor was estimated as the amount of mercury removed from coal with the rejects in relation to the amount of mercury in raw coal (coal feed) - Equation (2). Such a factor was also used in other works, among others (Pyka and Wierzchowski 201; Zajusz-Zubek and Konieczyński 2014). 


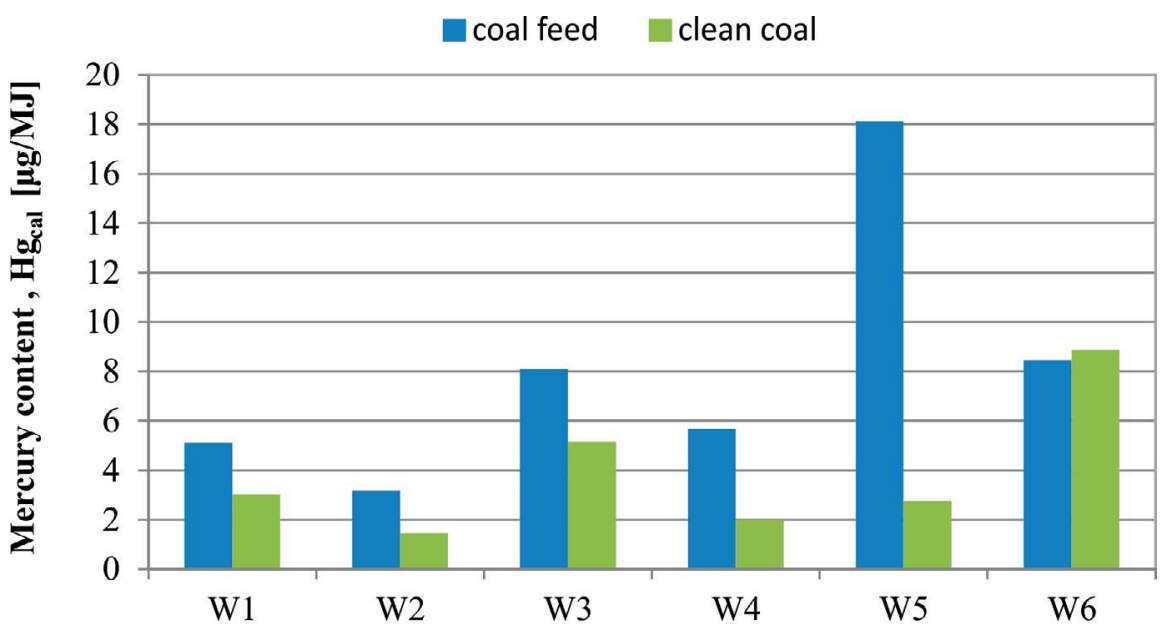

Hard coal number used in dry deshaling process

Fig. 3. Comparison of the mercury content related to the lower heating value of coal in raw coals (coal feed) and clean coals derived from the process of dry coal deshaling on an air concentrating table

Rys. 3. Porównanie zawartości rtęci w węglach surowych (nadawach) i koncentratach z procesu suchego odkamieniania przy wykorzystaniu powietrznego stołu koncentracyjnego w odniesieniu do ich wartości opałowej

$$
\eta_{H g_{\text {rejects }}}=\frac{\gamma_{\text {rejects }} \cdot H g_{\text {rejects }}}{H g_{\text {raw coal }}}
$$

$\stackrel{n}{b}$ where:

$\eta_{H_{-} \text {rejects }} \quad-$ the effectiveness factor of mercury removal from coal with rejects [\%],

$\mathrm{Hg}_{\text {rejects }} \quad-$ mercury content in the rejects $[\mu \mathrm{g} / \mathrm{kg}]$,

$\mathrm{Hg}_{\text {raw coal }} \quad-$ mercury content in raw coal (coal feed) $[\mu \mathrm{g} / \mathrm{kg}]$,

$\gamma_{\text {rejects }} \quad-$ yield of the rejects [\%].

The comparison of the values of the effectiveness factor of mercury removal from the analyzed coals is presented in Figure 4. The obtained results showed, that the dry deshaling process allowed for mercury removal for each case, however the effectiveness of mercury removal was highly diversified: from 9 to $96 \%$ (the average value was $44 \%$ ). The diversity of the mercury removal effectiveness should be related to the mode of mercury occurrence in coal as well as to coal properties and operation parameters of the dry deshaling process affecting the obtained yield of rejects. In order to illustrate the behavior of mercury in the process of dry deshaling of hard coal, the distribution of mercury among the obtained products is shown in Figure 5. The presented results show a significant potential of the dry deshaling process for mercury removal from hard coals. 

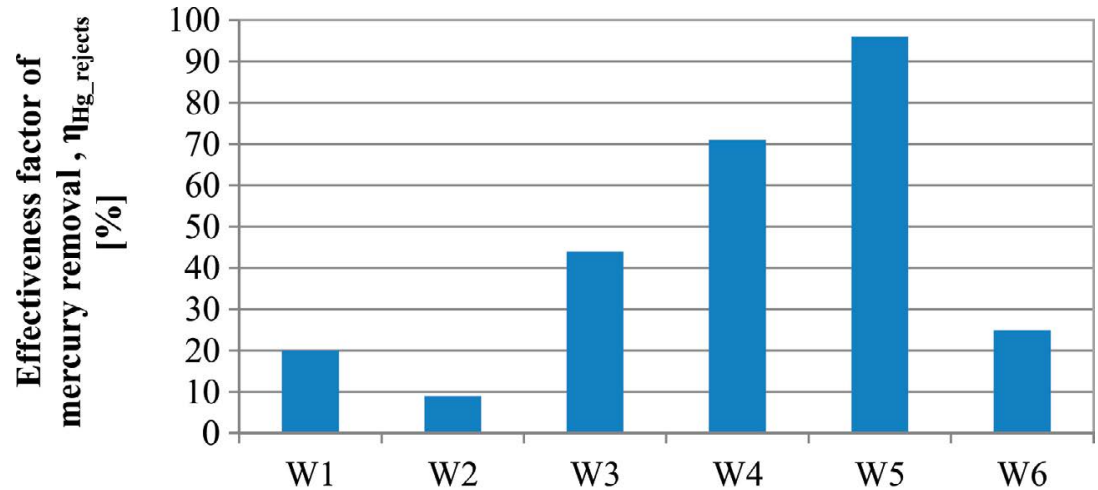

Hard coal number used in dry deshaling process

Fig. 4. Comparison of the values of the effectiveness factors of mercury removal from coal with rejects obtained in the process of dry deshaling on an air concentrating table

Rys. 4. Porównanie skuteczności usuwania rtęci z węgla kamiennego wraz z odpadami w procesie suchego odkamieniania przy wykorzystaniu powietrznego stołu koncentracyjnego

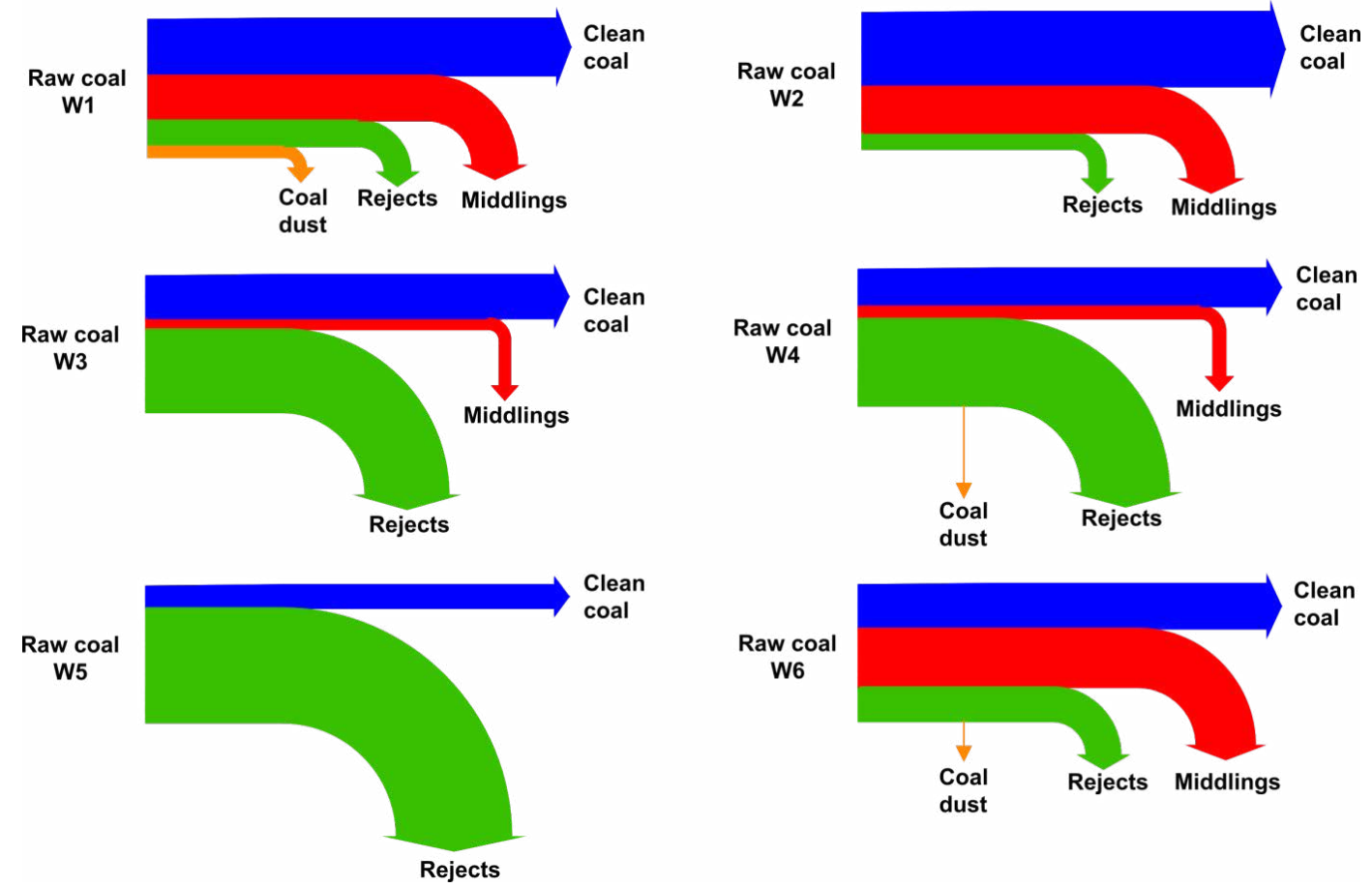

Fig. 5. Distribution of mercury in the process of dry deshaling of the examined hard coals

Rys. 5. Dystrybucja rtęci w procesie suchego odkamieniania przy wykorzystaniu powietrznego stołu koncentracyjnego 
The comparison of the ranges of the effectiveness of mercury removal from hard coal with rejects for the process of dry deshaling on an air concentrating table and the process of coal washing (Dziok and Strugała 2017) is presented in Figure 6. The comparison shows, that both dry and wet methods allowed for effective mercury removal from coal, although the effectiveness for both methods may vary within a relatively wide range. Interestingly enough, both the highest mercury removal effectiveness and the lowest mercury removal effectiveness were observed for the dry deshaling process.

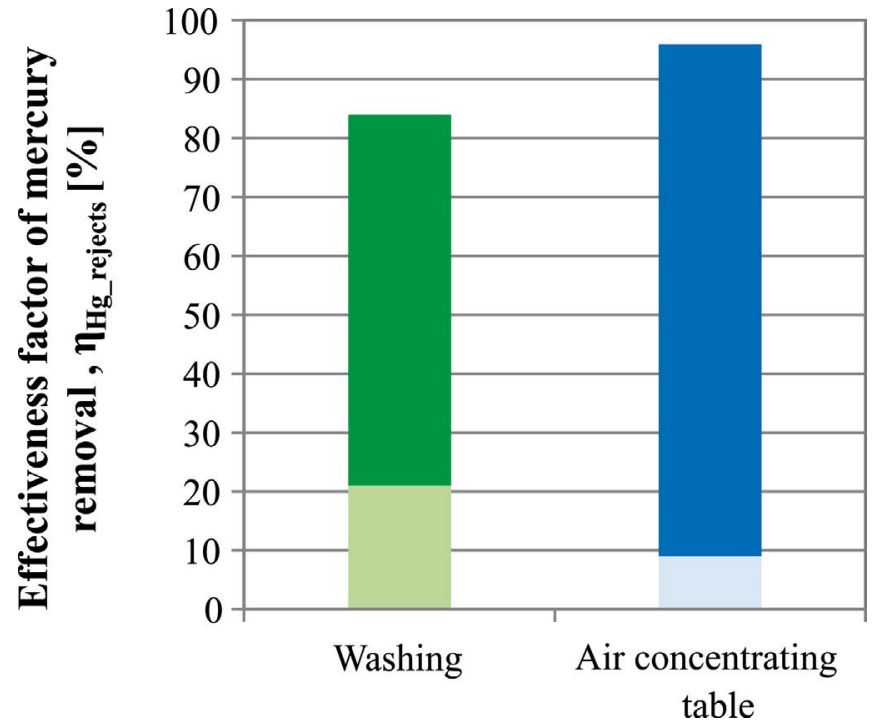

Fig. 6. Comparison of the ranges of effectiveness of mercury removal from coal with rejects for the process of dry deshaling on an air concentrating table and the process of coal washing (own results)

\footnotetext{
Rys. 6. Porównanie zakresów skuteczności usuwania rtęci z węgla kamiennego wraz z odpadami $\mathrm{w}$ procesie suchego odkamieniania przy wykorzystaniu powietrznego stołu koncentracyjnego oraz metodami wzbogacania na mokro (wyniki własne)
}

The significant potential of air concentrating tables for mercury removal from hard coal is also suggested by the data presented in Figure 7. It shows a comparison of the ranges of the effectiveness of mercury removal from coal which were obtained in this work and the effectiveness of the process of coal washing which is presented in literature. It could be concluded that the effectiveness of mercury removal from coal in the washing processes, both for Polish and foreign coals, is not significantly higher than in the dry deshaling process. The effectiveness is determined by the mode of mercury occurrence in coal rather than by the method of coal cleaning. Considering the lower investment and operating costs of the dry deshaling process when compared to the coal washing processes (Baic et al. 2015a), this process should be preferred in the selection of the method for mercury removal from hard coal. 


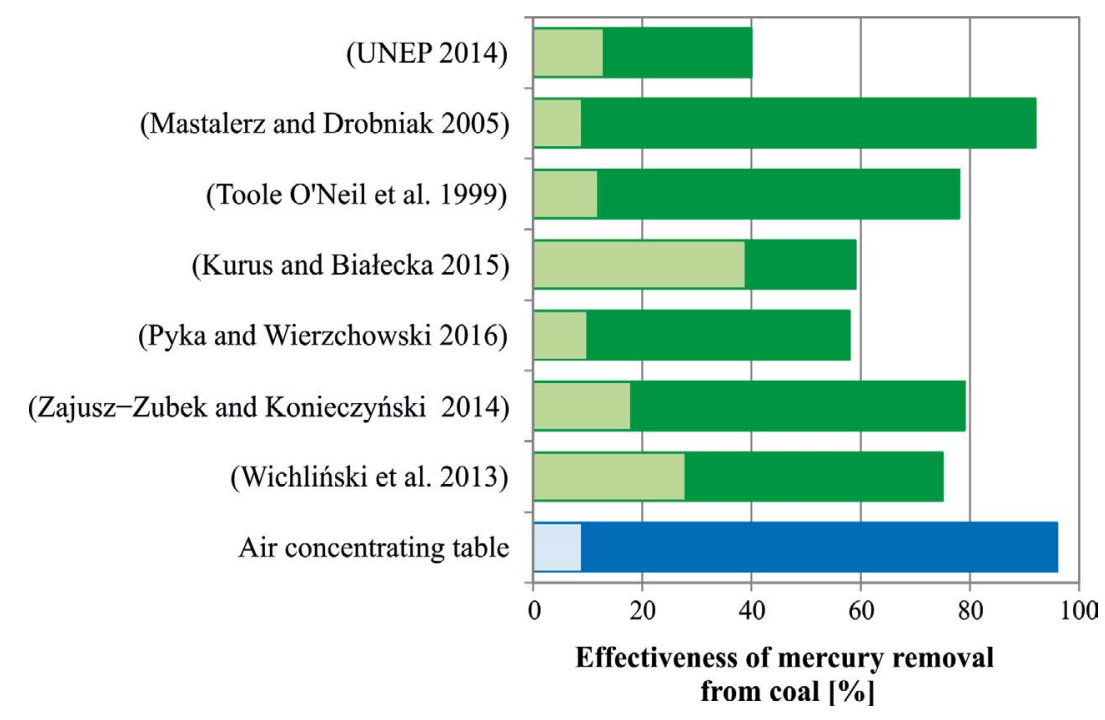

Fig. 7. Comparison of the ranges of effectiveness of mercury removal from coal with rejects for the process of dry deshaling on an air concentrating table (blue color) and for the process of coal washing (green color) - literature data

Rys. 7. Porównanie zakresów skuteczności usuwania rtęci z węgla kamiennego w procesie suchego odkamieniania przy wykorzystaniu powietrznego stołu koncentracyjnego (kolor niebieski) z danymi literaturowymi dla metod wzbogacania węgla na mokro (kolor zielony)

In addition, it should be pointed out that an additional possibility of increasing the effectiveness of mercury removal through the dry deshaling process exists. In the case of coals in which mercury occurs in the organic matter as well as in the inorganic constituents characterized by a relatively low temperature of mercury release, the obtained clean coals can be additionally treated in the process of mild pyrolysis. In this process coal is heated at the temperature of $200-400^{\circ} \mathrm{C}$ in the atmosphere of e.g. nitrogen or air. The sweep gas which contains mercury released from coal is directed on a sorbent bed in order to be purified. The spent sorbent is directed for disposal. The effectiveness of mercury removal from coal in this process is influenced by the following parameters: final process temperature, residence time in final temperature, heating rate, type and flow rate of sweep gas, as well as coal grain size (Chmielniak et al. 2015; Dziok et al. 2014; Dziok 2016). The idea of the combination of the dry deshaling process and the thermal pretreatment process is presented in Figure 8.

The proposed idea can be used in combination with the coal washing process as well. However, the higher content of moisture in the clean coal may cause an increase in the energy consumption in the thermal pretreatment process. In some cases (an exceptionally high moisture content in clean coal), an additional unit for moisture removal from coal before thermal pretreatment should be considered.

The obtained results indicate the occurrence of a positive synergy effect resulting from the combination of coal washing and coal mild pyrolysis (Dziok and Strugała 2017). Figure 9 


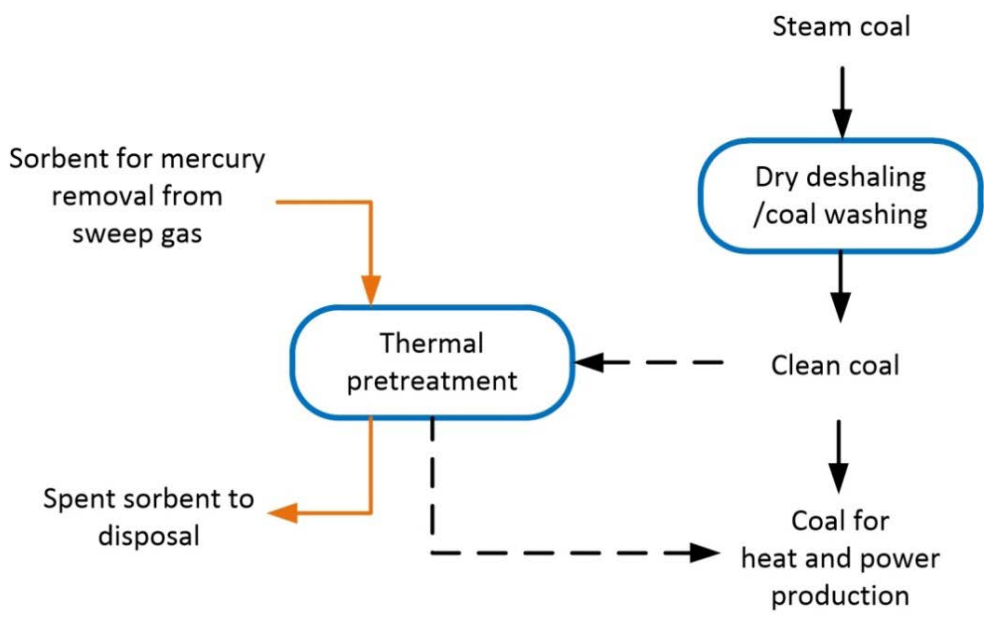

Fig. 8. Idea of the combination of the coal cleaning process and the thermal pretreatment process (dashed line means additional possibility for mercury removal from clean coal derived from the dry deshaling/coal washing process in the thermal pretreatment process)

Rys. 8. Koncepcja połączenia procesu wzbogacania z procesem wstępnej preparacji termicznej (linia przerywana oznacza dodatkową możliwość usunięcia rtęci z koncentratów otrzymanych w procesie suchego odkamieniania/wzbogacania w procesie ich wstępnej preparacji termicznej)

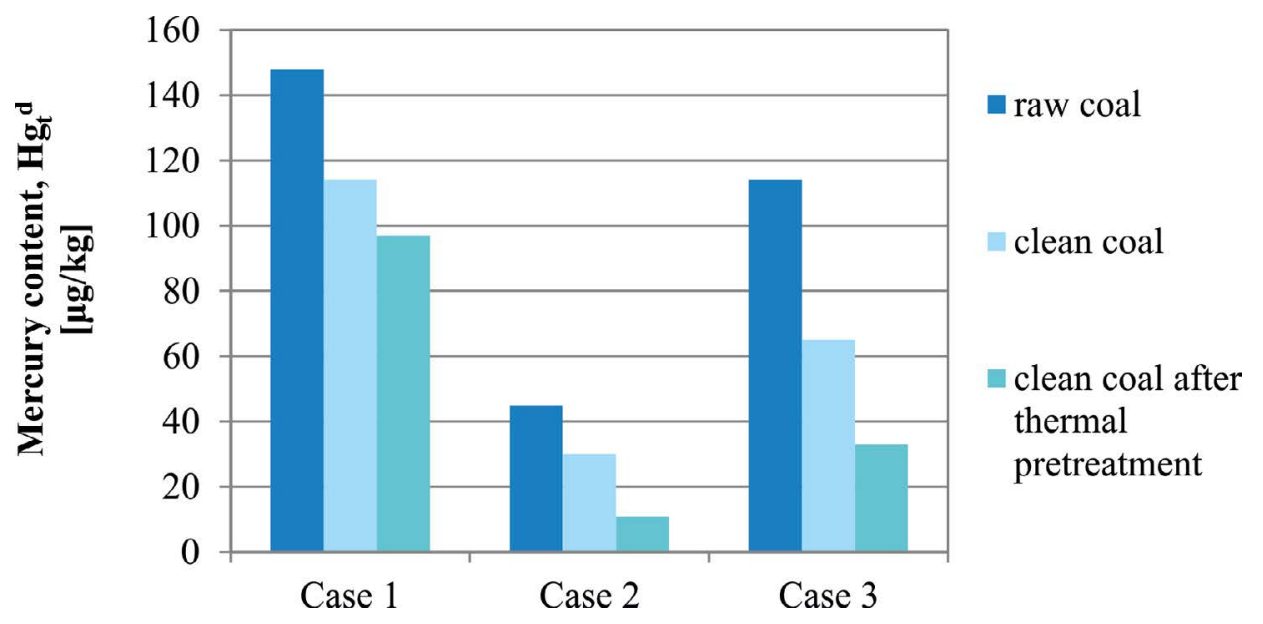

Fig. 9. Mercury contents in coal obtained as a result of the combination of the coal cleaning process and the mild pyrolysis process at $300^{\circ} \mathrm{C}$ (Dziok and Strugała 2017)

Rys. 9. Zawartości rtęci w węglu kamiennym uzyskane w wyniku połączenia procesu wzbogacania i wstępnej preparacji termicznej w temperaturze $300^{\circ} \mathrm{C}$ (Dziok i Strugała 2017) 
presents the mercury contents in raw coal, in clean coal which was derived from the coal washing process and in clean coal after the mild pyrolysis process at $300^{\circ} \mathrm{C}$. For each of the analyzed cases, the combination of both processes had a positive effect; however, it was diversified. This diversity could be connected with the different modes of mercury occurrence in individual coals.

\section{Conclusions}

The process of dry deshaling with the use of an air concentrating table allows for effective mercury removal from hard coals. However, the effectiveness of mercury removal is determined by the mode of mercury occurrence in coal and may vary significantly. For the analyzed coals, the effectiveness of mercury removal from coal with the rejects ranged from 9 to $96 \%$.

It should be emphasized, that the dry deshaling process did not allow for a decrease of mercury content for every coal. Although for five analyzed coals the mercury content in clean coal was lower in the range from 11 to $53 \%$, for one coal the mercury content was higher by $19 \%$. For that reason, a preliminary assessment of the mode of mercury occurrence in coal should be conducted prior to the selection of a method of its removal from coal. For that purpose, the results of an instrumental investigation could be used, i.e. the ones obtained with the usage of the electron probe micro-analyzer - EPMA (Dziok 2016; Dziok et al. 2017), or, at least, a statistical analysis of the relationship between the contents of mercury and various forms of sulfur and ash could be performed (Dziok et al. 2015a).

It should be pointed out, that the effect of decreasing the mercury content in coal is more evident when it is related to the amount of energy contained in coal (for example to the lower heating value of coal).

The effectiveness of mercury removal through the dry deshaling process is similar to the effectiveness of mercury removal from coal in the processes of coal washing. A similar effectiveness as well as lower investment and operating costs result in the fact that the dry deshaling process on an air concentrating table should be considered as a competitive method for the coal washing processes.

The effectiveness of mercury removal from coal in the process of dry deshaling could be additionally increased through the thermal pretreatment (mild pyrolysis) of clean coal derived from dry deshaling. This solution is only recommended for coals in which mercury occurs in the organic matter as well as in the inorganic constituents characterized by a relatively low temperature of mercury release.

This paper was prepared as a part of the statutory activity of the Faculty of Energy and Fuels at the AGH University of Science and Technology, No. 11.11.210.373. 


\section{REFERENCES}

Adamska, B. 2014. Konwencja Minamata w sprawie rtęci. Seminarium: Rtęć w przemyśle - Konwencja, ograniczanie emisji, technologia. Warszawa, 26 November, 2014 (in Polish).

Baic, I. and Blaschke, W. 2013. Analysis of the possibility of using air concentrating tables in order to obtain clean coal fuels and substitute natural aggregates. Energy Policy Journal 16(3), pp. 247-260 (in Polish).

Baic et al. 2015a - Baic, I., Blaschke, W., Góralczyk, S., Szafarczyk, J. and Buchalik, G. 2015. A new method for removing organic contaminants of gangue from the coal output. Annual Set The Environment Protection 17, pp. 1274-1285 (in Polish).

Baic et al. 2015b - Baic, I., Blaschke, W. and Sobko W. 2015. Research on energy coal deshaling on air concentration tables. Annual Set The Environment Protection 17, pp. $958-972$ (in Polish).

Baic et al. 2015c - Baic, I., Blaschke, W., Sobko, W. and Fraś, A. 2015. Application of air concentrating table for improvement in the quality parameters of the commercial product "Jaret". Journal of the Polish Mineral Engineering Society 16(1), pp. 221-226.

Burmistrz, P. and Kogut, K. 2014. Legal regulation on mercury emission [In:] Mercury as a coal combustion pollutant, (red.) Gołaś, J., Strugała, A. Warszawa: Oficyna Drukarska - Jacek Chmielewski, pp. 33-42.

Burmistrz et al. 2014 - Burmistrz, P., Czepirski, L., Kogut, K. and Strugała, A. 2014. Removing mercury from flue gases: a demo plant based on injecting dusty sorbents. Przem.Chem. 93(12), pp. 2014-2019 (in Polish).

Burmistrz et al. 2017 - Burmistrz, P., Kogut, K., Marczak, M. and Dziok, T. 2017. Mercury in Polish bituminous coals used in coke production. $2^{\text {nd }}$ International Conference on the Sustainable Energy and Environment Development-SEED'17. Kraków 14-17 November, 2017.

Chmielniak et al. 2015 - Chmielniak, T., Misztal, E., Mazurek, I. and Sajdak, M. 2015. Technology of pre-combustion mercury removal from coal. Przem. Chem. 94(4), pp. 480-486 (in Polish).

Diehl et al. 2004 - Diehl, S.F., Goldhaber, M.B. and Hatch, J.R. 2004. Modes of occurrence of mercury and other trace elements in coals from the warrior field, Black Warrior Basin, Northwestern Alabama. International Journal of Coal Geology 59, pp. 193-208.

Dziok et al. 2014 - Dziok, T., Strugała, A., Rozwadwoski, A. and Okońska, A. 2014. Effect of selected parameters of thermal pretreatment of bituminous coal on the mercury removal efficiency. Przem. Chem. 93(12), pp. 2034-2037 (in Polish).

Dziok et al. 2015a - Dziok, T., Strugała, A., Rozwadowski, A. and Macherzyński, M. 2015. Studies of the correlation between mercury content and the content of various forms of sulfur in Polish hard coals. Fuel 159(1), pp. 206-213.

Dziok et al. 2015b - Dziok, T., Strugała, A., Rozwadowski, A., Macherzyński, M. and Ziomber, S. 2015. Mercury in waste products from hard coal processing plants. Gospodarka Surowcami Mineralnymi - Mineral Resources Management 31(1), pp. 107-122 (in Polish).

Dziok, T. 2016. Badania zmiany zawartości rtęci na drodze przeróbki mechanicznej $i$ wstęnej preparacji termicznej węgli kamiennych. Rozprawa doktorska. Kraków: AGH Akademia Górniczo-Hutnicza w Krakowie, Wydział Energetyki i Paliw (in Polish).

Dziok et al. 2017 - Dziok, T., Strugała, A. and Włodek, A. 2017. Studies on mercury occurrence in inorganic constituents of Polish coals in the context of reducing mercury emission from coking plants. $2^{\text {nd }}$ International Conference on the Sustainable Energy and Environment Development - SEED'17, Kraków, 14-17 November, 2017.

Dziok, T. and Strugała, A. 2017. Method selection for mercury removal from hard coal. E3S Web of Conferences 14 (02007), pp. 1-10

European Commission 2017. Commission implementing decision (EU) 2017/1442 of 31 July 2017 establishing best available techniques (BAT) conclusions, under Directive 2010/75/EU of the European Parliament and of the Council, for large combustion plants.

Gworek, B. and Rateńska, J. 2009. Migracja rtęci w układzie powietrze - gleba - roślina. Ochrona Środowiska i Zasobów Naturalnych 41, pp. 614-623.

Kurus, K. and Białecka, B. 2015. Assessment of mercury load reduction capabilities in the hard coal preparation process. 15 ${ }^{\text {th }}$ International Multidisciplinary Scientific GeoConference. Albena 18-24 June, 2015. 
Krzyżyńska et al. 2011 - Krzyżyńska, R., Zhao, Y. and Hutson, N.D. 2011. Bench- and pilot-scale investigation of integratedremoval of sulphur dioxide, nitrogen oxides and mercury in a wet limestone scrubber. Annual Set The Environment Protection 13, pp. 29-50.

Mastalerz, M. and Drobniak, A. 2005. Vertical variations of mercury in Pennsylvanian coal beds from Indiana. International Journal of Coal Geology 62, pp. 223-236.

Ministerstwo Gospodarki 2015. Wnioski z analiz prognostycznych na potrzeby Polityki energetycznej Polski do 2050 roku. Załącznik 2 do Polityki energetycznej Polski do 2050 roku. Warszawa: Ministerstwo Gospodarki (in Polish).

Pirrone et al. 2010 - Pirrone, N., Cinnirella, S., Feng, X., Finkelman, R.B., Friedli, H.R., Mason, R., Mukherjee, A.B., Stracher, G.B., Streets, D.G. and Telmer, K. 2010. Global mercury emissions to the atmosphere from anthropogenic and natural sources. Atmospheric Chemistry and Physic, 10, pp. 5951-5964.

Porada et al. 2017 - Porada, S., Dziok, T., Czerski, G., Grzywacz, P. and Strugała, A. 2017. Examinations of Polish brown and hard coals in terms of their use in the steam gasification process, Gospodarka Surowcami Mineralnymi - Mineral Resources Management 33(1), pp. 15-34.

Pyka, I. and Wierzchowski, K. 2016. Split of mercury between products of coal cleaning versus mercury emissions reduction. Physicochem. Probl. Miner. Process. 52(1), pp. 193-203.

Sloss, L.L. 2015. Issue of mercury emissions from an EU perspective. Scientific and industrial conference: Mercury emission and possibilities of reducing it in the Polish energy sector, Kraków 13-14 May 2015.

Strezov et al. 2010 - Strezov, V., Evans, T.J., Ziolkowski, A. and Nelson, P.F. 2010. Mode of occurrence and thermal Stability of mercury in coal. Energy Fuels 24, pp. 53-57.

Toole-O’Neil et al. 1999 - Toole-O’Neil, B., Tewalt, S.J., Finkelman, R.B. and Akers, D.J. 1999. Mercury concentration in coal-unraveling the puzzle. Fuel 78, pp. 47-54.

UNEP 2013. Mercury - Time to act. Genewa: United Nations Environment Programme.

UNEP 2014. Assessment of the mercury content in coal fed to power plants and study of mercury emissions from the sector in India. Dhanbad: United Nations Environment Programme.

Uruski et al. 2015 - Uruski, Ł., Górecki, J., Macherzyński, M., Dziok, T. and Gołaś, J. 2015. The ability of Polish coals to release mercury in the process of thermal treatment. Fuel Processing Technology 140, pp. 12-20.

Wdowin et al. 2015 - Wdowin, M., Baran, P., Panek, R., Zarębska, K. and Franus, W. 2015. Possibility of exhaust gases purification from $\mathrm{Hg}^{0}$ and $\mathrm{CO}_{2}$ on synthetic zeolites from fly ash. Annual Set The Environment Protection 17, pp. 1306-1319.

Wichliński et al. 2013 - Wichliński, M., Kobyłecki, R. and Bis, Z. 2013. The investigation of mercury contents in polish coal samples. Archives of environmental protection 39(2), pp. 141-150.

Zajusz-Zubek, E. and Konieczyński, J. 2014 Coal cleaning versus the reduction of mercury and other trace elements' emission from coal combustion processes. Archives of Environmental Protection 40(1), pp. 115-127.

\section{WSTEPNA OCENA MOŻLIWOŚCI USUWANIA RTECI Z WEGLA KAMIENNEGO ZA POMOCĄ POWIETRZNYCH STOLÓW KONCENTRACYJNYCH}

\section{Słowa kluczowe}

węgiel kamienny, suche odkamienianie, usuwanie rtęci

\section{Streszczenie}

Rtęć charakteryzuje się silnie toksycznymi właściwościami. W środowisku podlega ona naturalnemu obiegowi, co powoduje, że każda emitowana jej ilość stanowi potencjalne zagrożenie dla zdrowia i życia ludzkiego. Do głównych źródeł antropogenicznej emisji rtęci należą procesy spalania 
węgla. Z tego też powodu w dniu 31 lipca 2017 r. decyzją Komisji Europejskiej przyjęte zostały limity emisyjne rtęci dla dużych obiektów energetycznego spalania.

Problem emisji rtęci jest szczególnie istotny dla Polski. Prognozy zużycia nośników energii pokazują, że węgiel pozostanie podstawowym źródłem pozyskiwania energii w naszym kraju przez najbliższe dziesięciolecia. Dlatego też konieczne będzie podjęcie działań mających na celu obniżenie jej emisji z elektrowni węglowych. Emisja rtęci z elektrowni węglowych może być ograniczona na szereg sposobów, które można podzielić na dwie główne grupy: metody post-combustion - polegające na usuwania rtęci ze spalin oraz metody pre-combustion - polegające na usuwaniu rtęci z węgla przed jego spaleniem.

Skuteczność usuwania rtęci z węgla uzależniona jest od sposobu występowania w nim rtęci. W przypadku jej występowania w składnikach mineralnych węgla wysoką skutecznością odznaczają się metody przeróbki mechanicznej. W przypadku występowania rtęci w substancji organicznej i/lub substancji mineralnej wewnętrznej metoda ta jest mało skuteczna. $\mathrm{Z}$ takich węgli rtęć może zostać usunięta w procesie jego termicznej preparacji (tzw. łagodnej pirolizy) polegającej na ogrzaniu węgla do temperatury $200-400^{\circ} \mathrm{C}$.

W pracy przeanalizowano możliwość usuwania rtęci z węgla kamiennego w procesie jego suchego odkamieniania przy wykorzystaniu powietrznych stołów koncentracyjnych. Analizie poddano węgle surowe (nadawy), koncentraty i odpady uzyskane z procesu suchego odkamieniania sześciu krajowych węgli kamiennych. W badanych próbkach oznaczono zawartość rtęci, a następnie porównano zawartość rtęci w węglach surowych i koncentratach oraz określono skuteczność jej usuwania z węgla wraz z odpadami.

Dla badanych węgli skuteczność usuwania rtęci wraz z odpadami w procesie suchego odkamieniania na powietrznym stole koncentracyjnym wyniosła od 9 do $96 \%$. Skuteczność ta jest zbliżona do skuteczności usuwania rtęci w procesach wzbogacania metodami mokrymi. Zbliżona skuteczność usuwania rtęci przy równocześnie niższych nakładach inwestycyjnych oraz kosztach eksploatacyjnych sprawiają, że proces suchego odkamieniania należy rozpatrywać jako konkurencyjny w stosunku do procesów wzbogacania węgla na mokro.

Istnieje także możliwość dodatkowego zwiększenia skuteczności usuwania rtęci w procesie suchego odkamieniania poprzez poddanie uzyskanego koncentratu procesowi wstępnej preparacji termicznej. Rozwiązanie to rekomendowane jest dla węgli, w których rtęć występuje w znaczących ilościach w substancji organicznej oraz w składnikach mineralnych o relatywnie niskiej temperaturze uwalniania rtęci.

Należy jednak zaznaczyć, że nie dla wszystkich przypadków proces suchego odkamieniania pozwala na obniżenie bezwzględnej zawartość rtęci w węglu. Dla pięciu analizowanych węgli zawartość rtęci spadła od 11 do 53\%, a dla jednego węgla wzrosła o 19\%. W przypadku odniesienia zawartości rtęci do ilości energii zwartej w węglu (wartości opałowej) efekt jej obniżenia jest bardziej widoczny. Dla pięciu analizowanych węgli tak wyrażona zawartość rtęci spadła o 36-83\%, a dla jednego węgla wzrosła, choć różnica ta nie była już tak znacząca i kształtowała się na poziomie 5\%. 


\section{PRELIMINARY ASSESSMENT OF THE POSSIBILITY OF MERCURY REMOVAL \\ FROM HARD COAL WITH THE USE OF AIR CONCENTRATING TABLES}

Keywords

hard coal, dry deshaling, mercury removal

Abstract

Mercury is characterized by highly toxic properties. The natural biogeochemical cycle of mercury occurs in the environment, which results in the fact that even a small amount of mercury emitted to the environment is a potential threat to human health. The process of coal combustion is one of the main sources of anthropogenic mercury emissions. For this reason, on 31 July 2017 the European Commission has adopted the mercury emission standards for large combustion plants.

The issue of mercury emissions is particularly important for Poland. Forecasts concerning energy consumption in Poland show that coal will be the main source for energy production in the coming decades. Therefore, actions enabling the reduction of mercury emissions from coal-fired power plants will have to be implemented. The mercury emissions from coal-fired power plants may be reduced through the application of a number of methods. These methods can be divided into two main groups: the post-combustion methods which allow for mercury removal from flue gases, and the pre-combustion methods which allow for mercury removal from coal before its combustion.

The effectiveness of mercury removal from coal is determined by the mode of its occurrence in coal. In the case of mercury occurrence in the adventitious inorganic constituents of coal, high effectiveness will be obtained in the coal cleaning processes. In the case of mercury occurrence in the organic matter as well as in the inherent inorganic constituents of coal, the effectiveness of this method will be low. Mercury could be removed from such coals through the process of thermal pretreatment at the temperature of $200-400^{\circ} \mathrm{C}$ (mild pyrolysis).

In the paper, the possibility of mercury removal from hard coal through the process of dry deshaling on an air concentrating table was examined. Six raw coals (coal feed), clean coals and the rejects derived from their dry deshaling were analyzed. The mercury content was measured in the examined samples. The content of mercury in raw coals and clean coals were compared. Additionally, the effectiveness of mercury removal from coal with rejects was determined.

For the analyzed coals, the effectiveness of mercury removal from coal in the process of dry deshaling on an air concentrating table ranged from 9 to $96 \%$. This effectiveness is similar to the effectiveness of mercury removal from coal in the processes of coal washing. It should be mentioned that, when compared to the coal washing processes, the dry deshaling process is characterized by lower investment and operating costs. Therefore, the dry deshaling process on an air concentrating table should be considered as a competitive method for the coal washing processes.

There is also a possibility of an increase in the mercury removal efficiency from coal in the process of dry deshaling as a result of the thermal pretreatment of clean coal derived from dry deshaling. This solution is only recommended for coals in which mercury occurs in the organic matter as well as in the inorganic constituents characterized by a relatively low temperature of mercury release. 
It should be emphasized that the dry deshaling process allowed for a decrease of mercury content is not suitable for every coal. Although for five of the analyzed coals the mercury content in clean coal was lower in the range from 11 to $53 \%$, for one coal the mercury content was higher by $19 \%$. The effect of decreasing the mercury content in coal is more evident when it is related to the amount of energy contained in coal (i.e. for example to the lower heating value). For five of the analyzed coals mercury content expressed in such a way decreased in the range from 11 to $53 \%$, and for one coal the mercury content was, however, higher. Nevertheless, the difference was not very significant (ca. 5\%). 
